\title{
Shell disease in Crangon crangon (Linnaeus, 1758): The interaction of temperature and stress response
}

\author{
Alexandra Segelken-Voigt ${ }^{\mathrm{a}, *}$, Gabrielle M. Miller ${ }^{\mathrm{a}}$, Gabriele Gerlach ${ }^{\mathrm{a}, \mathrm{b}, \mathrm{c}}$ \\ a Institute of Biology and Environmental Sciences, Carl von Ossietzky University Oldenburg, Carl von Ossietzky Str. 9-11, 26111 Oldenburg, Germany \\ ${ }^{\mathrm{b}}$ Helmholtz Institute for Functional Marine Biodiversity Oldenburg (HIFMB), Germany \\ ${ }^{\mathrm{c}}$ School of Marine and Tropical Biology and ARC Centre of Excellence for Coral Reef Studies, James Cook University, Queensland, Australia
}

\section{A R T I C L E I N F O}

\section{Keywords:}

Black spot disease

Climate warming

Crustacea

Metabolism

Molting

Survival

\begin{abstract}
A B S T R A C T
The prevalence of black spot shell disease is increasing among marine crustaceans worldwide. Rising seawater temperatures - often stressful for ectothermic species - are assumed to enhance the occurrence of shell disease. In the North Sea $>50 \%$ of local populations of the brown shrimp (Crangon crangon) are affected by the disease. While fisheries are suffering because diseased crustaceans are barely merchantable, the impact of shell disease on life history traits of crustaceans is little understood. To determine the role of temperature on the development of black spots and its implications for survival and physiology in the brown shrimp, a prolonged ( 3 months) thermal stress experiment was performed. We measured the increment of shell disease and the effect of molting in shrimps kept at control $\left(15^{\circ} \mathrm{C}=\right.$ equivalent to the seafloor temperature in the North Sea during sampling) and increased temperature $\left(20^{\circ} \mathrm{C}=\right.$ according to predictions for the end of the century). The resting metabolic rate was analyzed to determine the physiological state of diseased compared to non-diseased animals. In the present study, the warmer temperature in the range of $20^{\circ} \mathrm{C}$ did not increase the spot size of shell disease and no differences were observed between the two temperatures. The process of molting thereby seemed to diminish and in most of the cases even completely remove the signs of shell disease. At $15{ }^{\circ} \mathrm{C}$ but not at $20^{\circ} \mathrm{C}$, metabolic rate was reduced in diseased in contrast to healthy individuals. This study showed that shell disease might lead to a higher mortality rate and an impairment of the physiological state in $C$. crangon.
\end{abstract}

\section{Introduction}

The predicted water temperature of the world oceans will increase by $2-4{ }^{\circ} \mathrm{C}$ by the end of the century (IPCC, 2013) and the North Sea is one of the fastest warming continental shelf seas (Burrow et al., 2011). This raises the question of how marine invertebrates such as crustaceans in the North Sea will be affected by these changes and if they will be more stressed and more prone to diseases. The brown shrimp Crangon crangon is an ecological important shrimp due to its central role in the food web and as a valuable fishery resource along the northern European Atlantic Coast with total landings of up to 37,500 t in e.g. 2014 (ICES, 2015; Revill and Holst, 2004). To date, in England already $>80 \%$ (Dyrynda, 1998) and in the German Bight up to $50 \%$ of brown shrimps (Knust, 1990) were found to be infected with shell disease.

Shell disease is a common term for many different melanization of necrotic lesions, erosions, and disintegrations in crustaceans such as classical or endemic shell disease (Smolowitz et al., 1992; Sindermann, 1979) and epizootic shell disease (Shields, 2013; Smolowitz et al.,
2005). The proximate causes are thereby a dysbiosis of different chitinolytic and lipolytic bacteria such as Plesiomonas, Vibrio and Aquimarina (Cipriani et al., 1980; Feinmann et al., 2017; Getchell, 1989; Meres et al., 2012; Rosen, 1967). These pathogens are common in marine environments (Chistoserdov et al., 2005; Fisher et al., 1978; Hock, 1940; Malloy, 1978; Smolowitz et al., 1992) and are also present on the cuticle of healthy crustaceans (Rosen, 1967), in this case without any impact on the host. Under stressful environmental conditions (ultimate causes e.g. temperature increase, chemical pollution) or mechanical damage, they can degrade the cuticle and thereby facilitate the entrance of other pathogens (Baross et al., 1978; Cook and Lofton, 1973; Schlotfeldt, 1972; Shields, 2013; Vogan et al., 2001). Shell disease is therefore interpreted as a maladaptation to changing environmental conditions by decreasing the immunocompetence of the organisms (Chen et al., 1995; Dove et al., 2005) and reducing the defense mechanisms against pathogens (Sindermann, 1979; Tlusty et al., 2007). Due to the altered expression of different genes and hormones crustaceans can be energetically compromised or produce elevated levels of ecdysone, pointing towards changes in the molting behavior (Castro

\footnotetext{
* Corresponding author.

E-mail address: alexandra.segelken.voigt@uni-oldenburg.de (A. Segelken-Voigt).
} 
et al., 2006; Laufer et al., 2005; Tarrant et al., 2012). Shell disease can also be lethal due to secondary invading pathogens into the epidermis and underlying tissues causing sepsis of the host or impairments of locomotion and feeding functions (Dyrynda, 1998; Hoenig et al., 2017; Smolowitz et al., 1992). In all ectothermic organisms such as $C$. crangon, temperature determines and interacts with embryogenesis, growth, molting frequencies and also the reproduction and survival (Caudri, 1939; Hufnagl and Temming, 2011a; Lloyd and Yonge, 1947; Siegel et al., 2008; Tiews, 1954). Hence, increasing water temperatures can result in physiological stress and therefore decreased defense mechanisms, which in turn lead to more susceptibility to shell disease as has been shown in the American lobster (Homarus americanus) (Dove et al., 2005; Glenn and Pugh, 2006; Tlusty et al., 2007). Additionally, elevated water temperature enhances the amount of bacteria and thus the risk of an infection (Dove et al., 2005; Glenn and Pugh, 2006).

In the current study, a prolonged thermal stress experiment was performed to understand the effect of an elevated temperature on the onset and progression of shell disease in $C$. crangon, and to examine the effect of shell disease on the organisms' physiology.

\section{Materials and methods}

\subsection{Habitat and sampling of brown shrimps}

Crangon crangon is widely distributed in the North Sea and is also common in the Irish Sea, Baltic Sea, Mediterranean Sea, Black Sea and at the Atlantic coast. In the southeastern part of the North Sea the habitat of brown shrimps' is mostly characterized by sandy and muddy bottoms where they live buried in the sediment (Pinn and Ansell, 1993). The temperatures in the North Sea range from $0{ }^{\circ} \mathrm{C}$ in winter near the coast to $30^{\circ} \mathrm{C}$ in summer in the shallow areas and can locally vary by $10{ }^{\circ} \mathrm{C}$ within a few hours.

The experimental period lasted three months (sampling, acclimation and recording experiment), from July 2015 until October 2015. Shrimps were caught with a beam trawl by the research vessel FK Uthörn in the waters of the German Bight, North Sea southwest of the Island of Helgoland $\left(54^{\circ} 11^{\prime} \mathrm{N}, 7^{\circ} 53^{\prime} \mathrm{E}\right)$ and transported to the Biological Station Helgoland (BAH) of the Alfred Wegener Institute, Helmholtz Centre for Polar and Marine Research. After collection, male and nongravid females of a mean body length of $48( \pm 6) \mathrm{mm}$ were kept in holding tanks at $15{ }^{\circ} \mathrm{C}$ according to temperatures in the field. Shrimps were allowed to acclimate to the holding tanks and the surrounding conditions for a minimum period of three days. The water temperature in these holding tanks was then gradually heated to the required study temperature over 5 days $\left(1{ }^{\circ} \mathrm{C}\right.$ per day). Individuals, which were not immediately used in experiments, remained in these tanks under ad libitum conditions (see below) to replace dead animals during the experiment. Crangon crangon were fed every second day at dusk with live plankton collected locally or with frozen mysis (Mysis relicta). The remaining food was removed the next day. The entire aquarium was cleaned once a week to minimize possible accumulation of bacteria and organic waste.

\subsection{Experimental design}

Experiments were conducted in temperature-controlled rooms at low light conditions. The control group was held at $15{ }^{\circ} \mathrm{C}$ and the warm treatment group at $20^{\circ} \mathrm{C}$ (representative of the water temperature in the North Sea in summer plus $2-4{ }^{\circ} \mathrm{C}$ of the predicted ocean warming until the end of the century (IPCC, 2013)). The experimental setup of either temperature treatment consisted of five flow-through aquaria $(40 \times 60 \times 20 \mathrm{~cm} ; 33 \mathrm{~L})$ with an insert of 12 compartments each (Fig. 1A). Aquaria were supplied with filtered seawater directly pumped from the waters surrounding Helgoland with $2 \mathrm{~L} / \mathrm{min}^{-1}$ through perforated pipes located above the five boxes (Fig. 1) to provide fresh seawater supply to each compartment. The bottom of each compartment was covered with a mesh of $300 \mu \mathrm{m}^{2}$ so that the water could run through (Fig. 1B). Randomly chosen and apparently healthy brown shrimps were set into the aquaria (one animal per compartment) to prevent injuries and to allow for individual measurements of the size of black spots.

The water temperature was checked daily throughout the experiment using a digital thermometer and if necessary adjusted by heating devices. Shrimps were examined twice daily and all cases of molting or mortality were recorded. All individuals were photographed at the beginning of the experiment and after molting or death with a Nikon P7000 using a scale bar. Images were subsequently analyzed for body length and size of black spots using ImageJ software (http://rsb.info. nih.gov/ij/). The size of the spots was normalized by the body length of the individual and divided by the days of observation to receive the relative increment of black spots per day using the longest time span between two measuring points (start, molting or death of the organism).

\subsection{Resting metabolic rate}

The resting metabolic rate of shrimps was determined in closed chamber respiration and low light conditions. Animals were used, which had been in the experiment for a minimum of three weeks. A single shrimp was incubated in a $3.5 \mathrm{~L}$ sealed glass respiration chamber filled with filtered seawater ( 0.2 micron pore) (modified from Teschke et al., 2011). The animal (healthy or diseased) was randomly chosen from either of the two temperature treatments, and was placed on a mesh bottom separating the animal from a stir bar, which was driven by an electromagnetic stirrer. This setup was chosen to guarantee a constant mixing of the water. Measuring temperature corresponded to the temperature the animals had experienced in the two treatments. Oxygen consumption of the shrimps in the respiration chambers was measured with an Oxy-4mini 4 channel fiber optic oxygen transmitter (PreSens, Regensburg, Germany), allowing four parallel recordings. The oxygen concentration was recorded every $5 \mathrm{~min}$ for $24 \mathrm{~h}$ or until the $\mathrm{O}_{2}$ concentration reached $70 \%$. Oxygen consumption in chambers without shrimps provided information on potential metabolic activity of microorganisms (e.g. plankton and bacteria) in the filtered seawater. At the end of each incubation run, shrimps were removed from the chambers and photographed to calculate its body length and, if existing, the size of the shell disease spots.

It was determined that the shallowest respiration rates occurred between the hours of 0200 and $0700 \mathrm{pm}$. The decrease in oxygen concentration during this period was then used to calculate the resting metabolic rate in $\mathrm{mg} \mathrm{O}_{2} \mathrm{~g}^{-1} \mathrm{~h}^{-1}$, accounting for the different solubility of $\mathrm{O}_{2}$ in seawater at the different temperatures, corrected for oxygen saturation changes inside control chambers, and subsequently standardized for the body weight of the organisms according to Begum et al. (2009) and Teschke et al. (2011).

\subsection{Statistical analysis}

Statistical analyses were conducted with SPSS 24 (SPSS, Chicago, IL) and the significance threshold was set to $\alpha=0.05$ throughout the study. The data were tested for normality and homogeneity of variance using the Shapiro-Wilk and Levene's tests before further statistical analysis.

Kaplan-Meier analysis (Kaplan and Meier, 1958) was performed to test the effect of temperature and shell disease infection on mortality rates in the control and the warm temperature shrimps as well as in diseased and healthy ones. This procedure is a descriptive method, allowing an estimation of survival over time by using the log-rank method (Mantel, 1966), which gives equal weight to all time points. Spearman correlation was used to test the effect of the increase of shell disease per day on the survival time of the shrimp. Differences in the increase of black spots per day between the two temperature treatments 


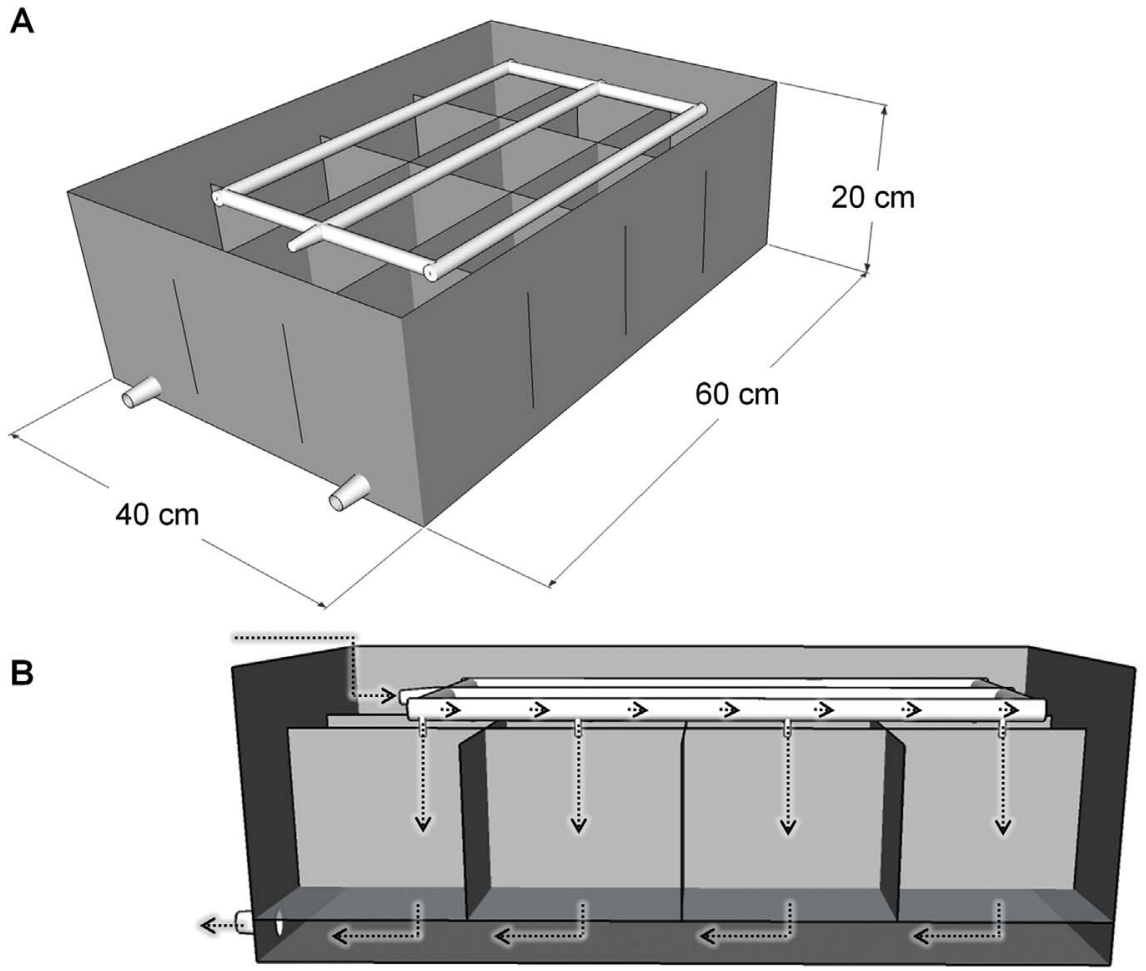

Fig. 1. A. Layout of an aquarium box $(40 \times 60 \times 20 \mathrm{~cm}$ and $33 \mathrm{~L}$ water volume) with twelve compartments giving space to twelve shrimps. B. The pipes above the aquarium were perforated and seawater could directly flow into each single compartment. The pipe was connected to a water-inlet-hose. At the bottom of each compartment a mesh $(300 \mu \mathrm{m})$ was attached. The outflow was at the bottom of the aquarium underneath this mesh layer. were compared using a Mann-Whitney- $U$ test. The effect of temperature and shell disease infection on resting metabolic rate was tested by a Kruskal Wallis test, followed by a Bonferroni post-hoc test. Subsequently, a general linear model (GLM) was performed to detect a possible effect of the independent variables 'Temperature' $\left(15^{\circ} \mathrm{C} / 20^{\circ} \mathrm{C}\right)$ and 'Health status' (healthy/diseased) as well as their interaction on the respiration rate $\left(\mathrm{mg} \mathrm{O}_{2} \mathrm{~g}^{-1} \mathrm{~h}^{-1}\right)$ as the response variable.

\subsection{Ethics statement}

All animal work was conducted according to the German animal protection law (Approval no.: 33.19-42502-05-15A542).

\section{Results}

\subsection{Occurrence of shell disease}

Since there were no statistically significant differences among experimental aquaria per treatment (Kruskal Wallis: control: chi $^{2}=6.831 ; \mathrm{p}=0.145$, warm: chi $^{2}=1.704 ; \mathrm{p}=0.790$ ), we pooled the data and compared the increase of black spots per day between the two temperature treatments. A total of 110 shrimps were analyzed in this study: 54 shrimps in the warm temperature treatment and 56 in the control. Almost 23\% (25 shrimps: 12 control and 13 warm) did not show any signs of shell disease during the whole time of investigation. On the shrimps where the shell disease developed during the experimental phase, the black spots grew approximately $0.17( \pm 0.15) \mathrm{mm}^{2}$ ([mean $\pm \mathrm{SD}]$ ) per day in the control, and $0.15( \pm 0.13) \mathrm{mm}^{2}$ per day in the warm temperature treatment. Fig. 2 shows an example of the expansion of the black spots: at the beginning the spot was $0.59 \mathrm{~mm}^{2}$ large (Fig. 2A) and reaching $8.71 \mathrm{~mm}^{2}$ within 30 days what are $0.26 \mathrm{~mm}^{2}$ per day (Fig. 2B). No significant differences were detected between the increase of black spots per day between the temperature treatments (Mann Whitney- $U: \mathrm{z}=0.863 ; \mathrm{p}=0.388$ ).

\subsection{Molting rate and its effect on shell disease}

During the experimental period $50 \%$ of the individuals in the control temperature and $55.5 \%$ in the warm temperature underwent a complete molting; but differences between temperatures were statistically non-significant $\left(\mathrm{chi}^{2}=0.105 ; \mathrm{p}=0.746\right.$ ). In the warm treatment four organisms molted twice during the time of investigation and none of the organisms in the control temperature. In almost all animals the signs of shell disease spots disappeared after molting except for two individuals $(7.14 \%)$ in the control and four $(13.3 \%)$ in the warm treatment. In these organisms the black spots diminished by 48.1 ( \pm 21.4 ) \% in size, but were still visible after molting (see Fig. 2C). These individuals died within the next 1-5 days. If the spots remained or disappeared during molting was independent of the size of the spots.

\subsection{Mortality rate}

At the control temperature, the survival rates of the healthy shrimps (53.3 \pm 17.5 days) were significantly higher than those of the diseased organisms (37.2 \pm 13.5 days; chi $^{2}=10.236 ; \mathrm{p}=0.001$ Fig. 3$)$. Also in the warm temperature group the survival rates of the healthy individuals ( $44.8 \pm 18.5$ days) were higher than the one of the diseased shrimps $\left(33.5 \pm 15.5\right.$ days; chi $^{2}=3.838 ; \mathrm{p}=0.041$ Fig. 3$)$.

A Spearman's correlation was run to determine the relationship between survival time and increase in shell disease. There was a medium monotonic correlation between shell disease and survival (Spearman correlation: $\mathrm{R}_{\mathrm{s}}=-0.413 ; \mathrm{p}<0.0001$ Fig. 4).

\subsection{Respiration}

In total, the respiration rate of 51 individuals was measured: 26 shrimps of the warm treatment ( 15 healthy and 11 diseased) and 25 of the control temperature (15 healthy and 10 diseased). Four organisms had to be excluded from the analysis because of exceptional high respiration rates, due to molting the next day.

The resting metabolic rate of $C$. crangon showed a significant interaction between temperature and health status (GLM, Table 1). As 

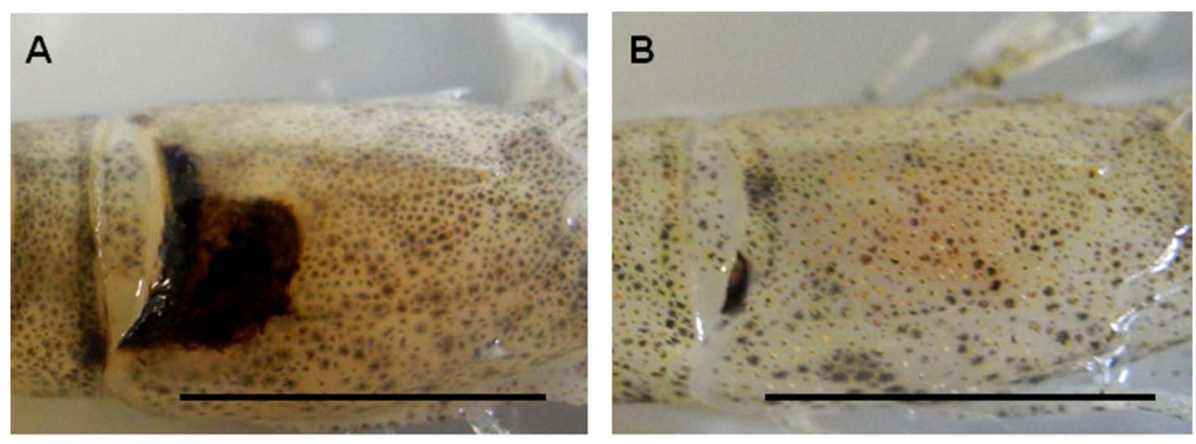

Fig. 2. A. Initial beginning of shell disease (spot area $=$ $0.59 \mathrm{~mm}^{2}$ ) and B. development of shell disease (spot area $\left.=8.71 \mathrm{~mm}^{2}\right)$ after 30 days $\left(0.26 \mathrm{~mm}^{2}\right.$ per day). C. Crangon crangon with spots of shell disease after molting and before shown by the exuvia. Scale $=1 \mathrm{~cm}$.

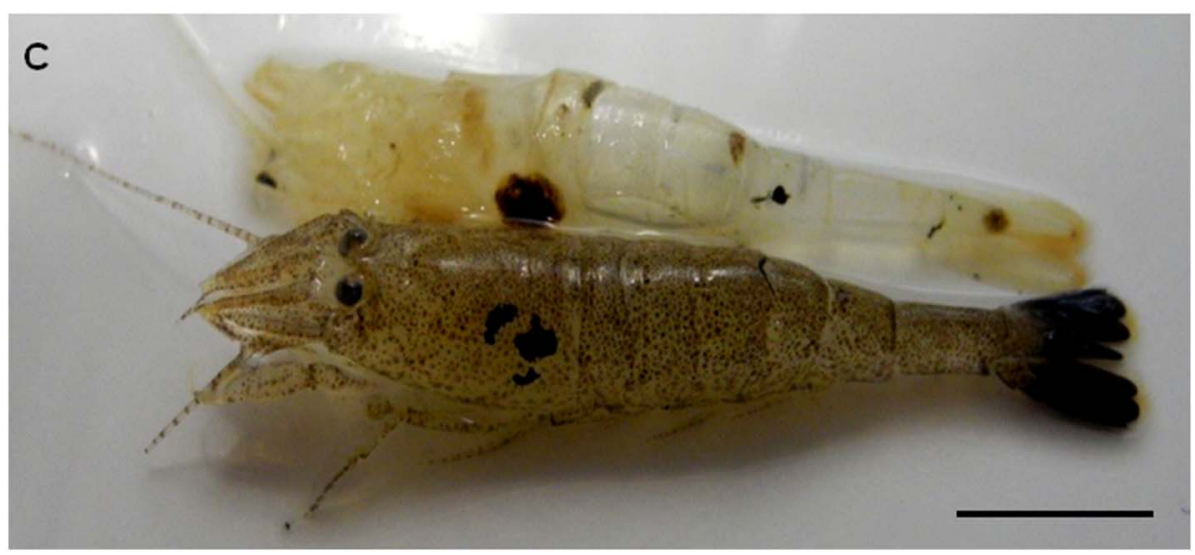

shown in Fig. 5, the healthy organisms at the control temperature had significantly higher respiration rates $\left(0.281 \pm 0.083 \mathrm{mg} \mathrm{O}_{2} \mathrm{~g}^{-1} \mathrm{~h}^{-1}\right)$ compared to the diseased shrimps $\left(0.194 \pm 0.052 \mathrm{mg} \mathrm{O}_{2} \mathrm{~g}^{-1} \mathrm{~h}^{-1}\right.$, Bonferroni post-hoc test: mean $=0.088, p=0.032$ ). In the warm treatment, no differences existed between the respiration rates of the healthy $\left(0.315 \pm 0.069 \mathrm{mg} \mathrm{O}_{2} \mathrm{~g}^{-1} \mathrm{~h}^{-1}\right)$ and diseased shrimps $\left(0.311 \pm 0.069 \mathrm{mg} \mathrm{O}_{2} \mathrm{~g}^{-1} \mathrm{~h}^{-1} ; \quad\right.$ Bonferroni post-hoc test: mean $=0.004, p=1.000$ ). The respiration rates of the healthy shrimps in the warm treatment and control temperature were the same (Bonferroni post-hoc test: mean $=0.034, p=1.000$ ), whereas the diseased organisms from the warm treatment had a significantly higher respiration rate (Bonferroni post-hoc test: mean $=0.117, \mathrm{p}=0.004$ ) compared to the ones of the control temperature.

\section{Discussion}

Our results suggest that increasing water temperature alone did not promote the course of shell disease in Crangon crangon. Nevertheless, the presence of black spots correlated with significant higher mortality rates at both temperatures, pointing towards a negative impact of the disease on the shrimps. These higher mortality rates might be attributed to a secondary bacterial infection or gill damage. Accordingly, Castro et al. (2006); Smolowitz et al. (1992) and Vogan et al. (2001) showed that in shell diseased American lobster (Homarus americanus) the chitinolytic and lipolytic bacteria seem to destroy the cuticle of the shrimp, which is composed of chitin and lipids. These pathogens, penetrating into the soft underlying tissue, are causing sepsis of the host or the host is dying during molting because of an incomplete withdrawal of the cuticle.

In the present study, the warmer temperature per se did not increase

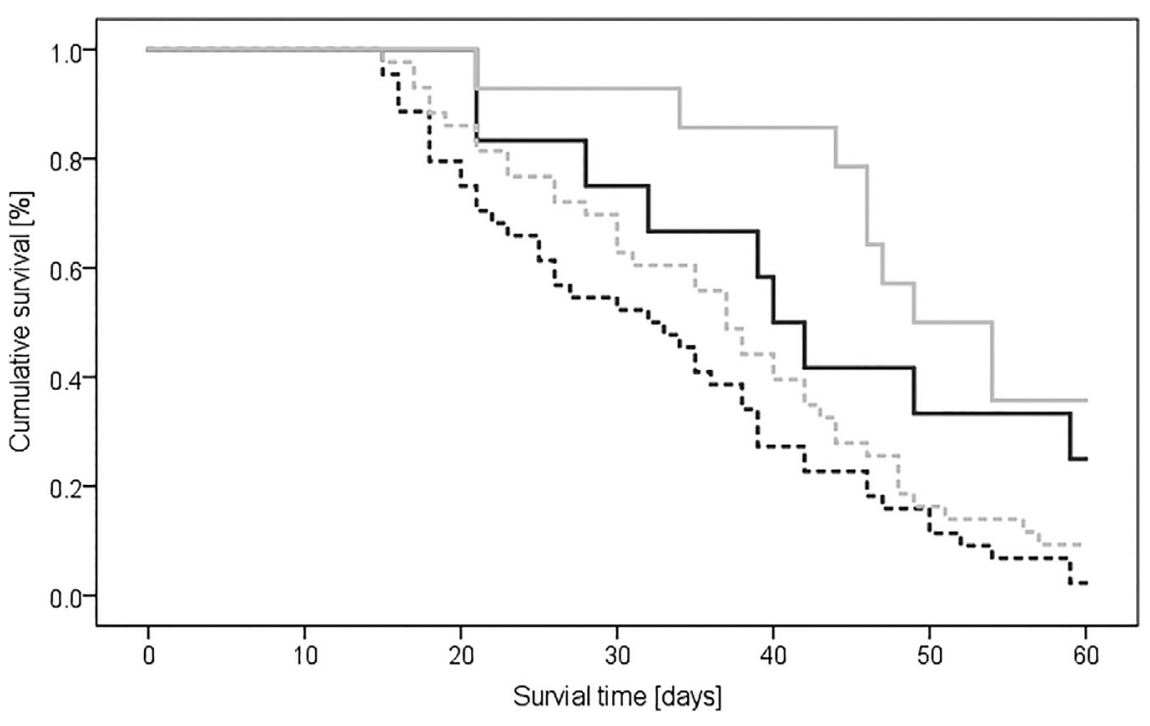

Fig. 3. Survival rates of healthy (continuous line) and diseased (dotted line) Crangon crangon in the two different temperature treatments. Grey $=$ control temperature $\left(15^{\circ} \mathrm{C}\right)$; black $=$ warm temperature $\left(20^{\circ} \mathrm{C}\right)$. 


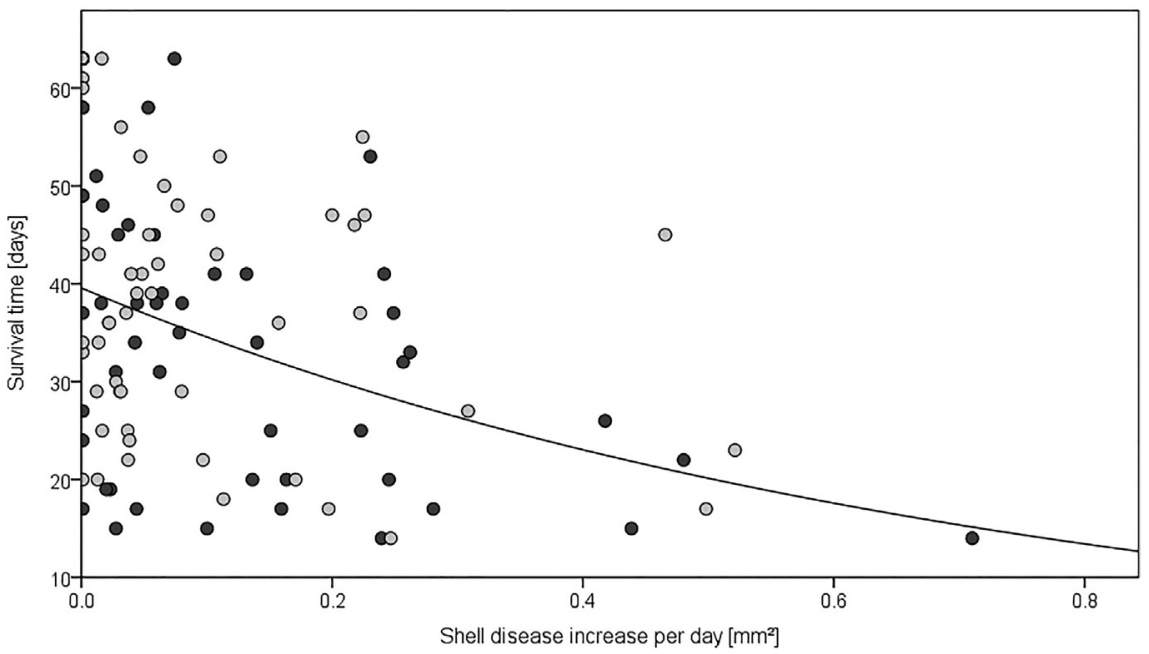

Fig. 4. Exponential relationship of shell disease measured as size of black spots per day $\left[\mathrm{mm}^{2}\right]$ and the survival time of Crangon crangon in days $\left(\mathrm{r}^{2}=0.173 ; \mathrm{F}=22.55 ; \mathrm{p}<0.0001\right)$. The dots are representative for the increase of shell disease per day in animals exposed to control $\left(15^{\circ} \mathrm{C}\right.$, grey) and warm temperature $\left(20^{\circ} \mathrm{C}\right.$, black).
Table 1

Results of the GLM-analysis showing the effect of two different temperatures $\left(15^{\circ} \mathrm{C}\right.$ / $20^{\circ} \mathrm{C}$ ) and health status (healthy/diseased) as fixed factors and the interaction of both on respiration rate of Crangon crangon as the response variable.

\begin{tabular}{llllll}
\hline Source & $\begin{array}{l}\text { Type III sum } \\
\text { of squares }\end{array}$ & df & $\begin{array}{l}\text { Mean } \\
\text { square }\end{array}$ & F & p-Value \\
\hline $\begin{array}{llllll}\text { Intercept } \\
\text { Temperature }\end{array}$ & 3.769 & 1 & 3.769 & 762.195 & $<0.001$ \\
$\begin{array}{l}\text { Health status } \\
\text { Temperature } * \text { Health }\end{array}$ & 0.068 & 1 & 0.068 & 13.703 & 0.001 \\
$\quad 0.024$ & 1 & 0.024 & 4.870 & 0.032 \\
$\quad$ status & 0.020 & 1 & 0.020 & 4.055 & 0.047 \\
Error & 0.232 & 47 & 0.005 & & \\
\hline
\end{tabular}

$\mathrm{R}^{2}=0.297$ (adjusted $\mathrm{R}^{2}=0.253$ ).

the spot size of shell disease, but the process of molting seemed to reduce and in some cases even completely vanished the symptoms of shell disease. The influence of temperature on the development of shell disease has been described for lobsters before. But contrasting to our finding, a positive correlation was observed in lobsters between a period of rising seawater temperature and (epizootic) shell disease prevalence (Castro et al., 2006; Glenn and Pugh, 2006; Tlusty and Metzler, 2012). In contrast to $C$. crangon, lobsters do not molt as often as shrimps and retain their shells for a longer timescale (Hufnagl and Temming, 2011b; Hughes and Matthiessen, 1962). Therefore, it might be possible that bacteria living on lobster shells have more time to cause shell disease. On average, lobster molt only once a year to gain in size or to reproduce whereas shrimps have a faster intermolt period of approximately three weeks (Hufnagl and Temming, 2011b; Hughes and Matthiessen, 1962). Thus, elevated sea water temperatures might not enhance the growth of black spots in diseased brown shrimps, but instead promoted the relief of the disease due to a higher molting rate (see e.g. Tlusty and Metzler, 2012). Accordingly, our results suggest that that molting improves the health status of already infected brown shrimps in the majority of the cases.

Further, independent of temperature or the size of the spots, $>80 \%$ of the previously diseased individuals did not show any signs of infection post molting. This is consistent with Smolowitz et al. (1992) and Glenn and Pugh (2006) who noted that early signs of shell disease can disappear after molting in the American lobster, whereas Schlotfeldt (1972) still observed a few black spots after molting, when the bacteria had already invaded the soft underlying tissues. It is known from literature that crustaceans, such as $C$. crangon, have a higher molting rate and therefore a shorter intermolt period at increasing seawater temperatures (Tiews, 1954). In the present study, approximately $13 \%$ of the shrimps in the warm temperature treatment molted twice, pointing towards faster molting intervals in that treatment. We assume that in warmer water, growth of spots was counterbalanced by a higher molting rate. This could explain why we did not see differences in the increase of black spots, comparing the diseased animals in control and the warm temperature treatments. Likewise, Tlusty and Metzler (2012) stated that the American lobster showed a higher prevalence of (epizootic) shell disease in the intermediate temperature of $15{ }^{\circ} \mathrm{C}$ compared to $20{ }^{\circ} \mathrm{C}$ because of a shorter intermolt period in the high temperature

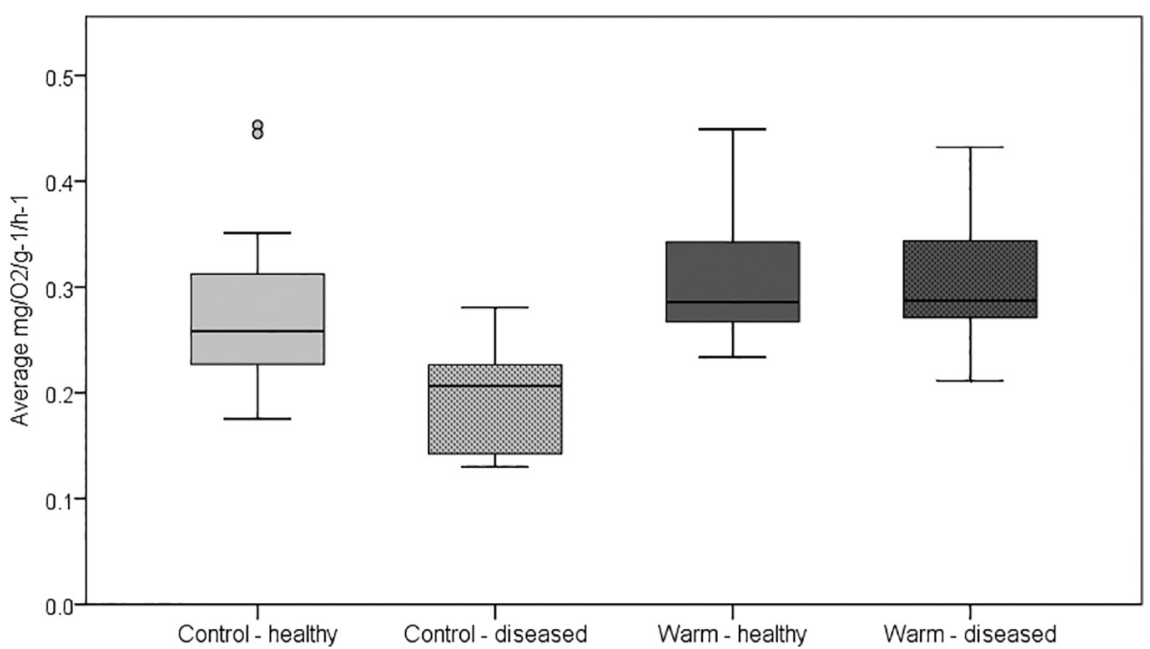

Fig. 5. Average oxygen consumption ( $\mathrm{mg} \mathrm{O}_{2} \mathrm{~g}^{-1} \mathrm{~h}^{-1}$ ) of diseased and healthy Crangon crangon exposed to of the control $\left(15^{\circ} \mathrm{C}\right.$, grey) and warm temperature $\left(20^{\circ} \mathrm{C}\right.$, black). Dots show outliers. Values shown are median (center line in box) with upper and lower quartile. Whiskers representing the highest respectively the lowest values and circles indicate the outliers. 
treatment. Longer intermolt periods at $15{ }^{\circ} \mathrm{C}$ allow the pathogens to spread, and increase the chance of infection and larger lesions. This demonstrates the importance of including information on molting, when studying shell disease or other diseases developing on the cuticle of crustaceans.

The respiration rate of $C$. crangon was apparently affected by shell disease in the control temperature, suggesting an impairment of respiratory function due to the disease. This reduced respiration rate in diseased organisms is surprising at first glance. However, crustaceans have no adaptive immune system and therefore hemocytes play an important role for phagocytosis and encapsulation of bacteria or small particles.

Shell disease can thereby cause significant changes in the immune system of crustaceans. It was previously described that the bacterial counts in the hemolymph are increasing with the severity of the disease, possibly resulting from a reduced ability of the host to clear the pathogens in their plasma (Homerding et al., 2012; Vogan et al., 2002). The hemocytes recognize and remove these foreign matters which become trapped in the gills, what might result in a decline in the respiration (Martin et al., 2000; Smith and Ratcliffe, 1980; White and Ratcliffe, 1982). Accordingly, in the Atlantic blue crab Callinectes sapidus and in the whiteleg shrimp Litopenaeus vannamei the infection with the bacterial pathogen Vibrio campbellii, impaired the respiration function and a metabolic depression of $>30 \%$ was observed (Burnett et al., 2006; Scholnick et al., 2006; Thibodeaux et al., 2009). The present and recent studies show, that a strong immune response and a protective function of the gill against invading pathogens might lead to an impairment of the respiratory function, probably due to these aggregated hemocytes that inhibit the lamellas of the gills.

Interestingly, in the present study, such an effect was not observed in $C$. crangon exposed to the warm treatment. In poikilotherms like $C$. crangon, an increase of temperature led to higher standard metabolic rates (Van Donk and De Wilde, 1981), which led to higher oxygen consumption rates in the present study. Therefore, it might be possible that the temperature effect masks the impact of the black spots on the organism's oxygen consumption rates. Each organism has its optimum temperature which is defined as the point at which the reaction rate and physiological performances is maximal (Angilletta et al., 2002; Reiser et al., 2014). Comparing the effect of temperature on the growth rates of $C$. crangon in various studies, Hufnagl and Temming (2011b) observed that the optimal temperature range of adult brown shrimp was between 18 and $22{ }^{\circ} \mathrm{C}$. Also Tiews (1970) mentioned a similar optimal temperature range for C. crangon of $15-20{ }^{\circ} \mathrm{C}$ and Freitas et al. (2007) determined $23{ }^{\circ} \mathrm{C}$ as the optimum temperature. Thus, it might be possible that the effect of shell disease could not be detected in the individuals living at $20{ }^{\circ} \mathrm{C}$ because they are at their physiological optimum, and metabolic processes were operating well such as coping with the consequences of the disease.

\section{Conclusion}

This study showed that shell disease might causes an impairment of the physiological state, and a higher mortality in C. crangon. Although in our experiment we did not observe a clear temperature effect on the susceptibility of brown shrimps to shell disease, we cannot exclude an impairment of the immunocompetence of the brown shrimp in vivo in response to rising environmental temperatures predicted for the future. In our study, higher temperatures in the range of $20^{\circ} \mathrm{C}$ did not increase the appearance and the symptoms of shell disease, probably due to the induction of faster molting rates. Nevertheless, higher seawater temperatures might affect the growth and deposition of the cuticle, and, furthermore might increase the bacteria load in the seawater. The combination of those factors might then influence shell disease infection of C. crangon.

\section{Acknowledgments}

We are thankful to the Biological Station of Helgoland (AWI) and the captain and crew of the FK Uthörn for providing the facilities and for sampling of the experimental animals. Special thanks to Alexandra Kraberg and Uwe Nettlemann for their help during the experimental phase on Helgoland. Thanks to Andreas Sommer (University of Oldenburg) for building the aquarium set-up.

\section{References}

Angilletta, M.J., Niewiarowski, P.H., Navas, C.A., 2002. The evolution of thermal physiology in ectotherms. J. Therm. Biol. 27, 249-268.

Baross, J.A., Tester, P.A., Morita, R.Y., 1978. Incidence, microscopy, and etiology of exoskeleton lesions in the Tanner crab, Chionoecetes tanneri. J. Fish. Res. Board Can. $35,1141-1149$.

Begum, S., Basova, L., Strahl, J., Sukhotin, A., Heilmayer, O., Philipp, E., Brey, T., Abele, D., 2009. A metabolic model for the ocean quahog Arctica islandica - effects of animal mass and age, temperature, salinity, and geography on respiration rate. J. Shellfish Res. 28, 533-539.

Burnett, L.E., Holman, J.D., Jorgensen, D.D., Ikerd, J.L., Burnett, K.G., 2006. Immune defense reduces respiratory fitness in Callinectes sapidus, the Atlantic blue crab. Biol. Bull. 211, 50-57.

Burrow, M.T., Schoeman, D.S., Buckley, L.B., Moore, P., Poloczanska, E.S., Brander, K.M., Brown, C., Bruno, J.F., Duarte, C.M., Halpern, B.S., Holding, J., Kappel, C.V., Kiessling, W., O'Connor, M.I., Pandolfi, J.M., Parmesan, C., Schwing, F.B., Sydeman, W.J., Richardson, A.J., 2011. The pace of shifting climate in marine and terrestrial ecosystems. Science 334, 652-655.

Castro, K.M., Factor, J.R., Angell, T., Landers Jr., D.F., 2006. The conceptual approach to lobster shell disease revisited. J. Crustac. Biol. 26, 646-660.

Caudri, L., 1939. Einfluss der Temperatur und des Salzgehalts auf die Sterblichkeit von Garnelen. Arch. Néerl. Zool. 3, 179-196.

Chen, J.C., Lin, M.N., Ting, Y.Y., Lin, J.N., 1995. Survival, haemolymph osmolality and tissue water of Penaeus chinensis juveniles acclimated to different salinity and temperature levels. Comp. Biochem. Physiol. A 110, 253-258.

Chistoserdov, A.Y., Smolowitz, R., Mirasol, F., Hsu, A., 2005. Culture-dependent characterization of the microbial community associated with epizootic shell disease lesions in American lobster, Homarus americanus. J. Shellfish Res. 24, 741-747.

Cipriani, G.R., Wheeler, R.S., Sizemore, R.K., 1980. Characterization of brown spot disease of Gulf Coast shrimp. J. Invertebr. Pathol. 36, 255-263.

Cook, D.W., Lofton, S.R., 1973. Chitinoclastic bacteria associated with shell disease in Penaeus shrimp and the blue crab (Callinectes sapidus). J. Wildl. Dis. 9, 154-159.

Dove, A.D., Allam, B., Powers, J.J., Sokolowski, M.S., 2005. A prolonged thermal stress experiment on the American lobster, Homarus americanus. J. Shellfish Res. 24, $761-765$.

Dyrynda, E., 1998. Shell disease in the common shrimp Crangon crangon: variations within an enclosed estuarine system. Mar. Biol. 132, 445-452.

Feinmann, S.G., Unzueta Martínez, A., Bowen, J.L., Tlusty, M.F., 2017. Fine-scale transition to lower bacterial diversity and altered community composition precedes shell disease in laboratory-reared juvenile American lobster. Dis. Aquat. Org. 124, 41-54.

Fisher, W.S., Nilson, E.H., Steenbergen, J.F., Lightner, D.V., 1978. Microbial diseases of cultured lobsters: a review. Aquaculture 14, 115-140.

Freitas, V., Campos, J., Fonds, M., Van der Veer, H.W., 2007. Potential impact of tem perature change on epibenthic predator-bivalve prey interactions in temperate estuaries. J. Therm. Biol. 32, 328-340.

Getchell, R., 1989. Bacterial shell disease in crustaceans: a review. J. Shellfish Res. 8, 1-6.

Glenn, R.P., Pugh, T.L., 2006. Epizootic shell disease in American lobster (Homarus americanus) in Massachusetts coastal waters: interactions of temperature, maturity, and intermolt duration. J. Crustac. Biol. 26, 639-645.

Hock, C.W., 1940. Decomposition of chitin by marine bacteria. Biol. Bull. 79, 199-206. Hoenig, J.M., Groner, M.L., Smith, M.W., Vogelbein, W.K., Taylor, D.M., Landers Jr., D.F., Gauthier, D.T., Sadler, P., Matsche, M., Haines, A., Small, H.J., Shields, J.D., 2017. Impact of disease on survival of three commercially fished species. Ecol. Appl. http:// dx.doi.org/10.1002/eap.1595.

Homerding, M., McElroy, A., Taylor, G., Dove, A., Allam, B., 2012. Investigation of epizootic shell disease in American lobsters (Homarus americanus) from Long Island Sound: II. Immune parameters in lobsters and relationships to the disease. J. Shellfish Res. 31, 495-504.

Hufnagl, M., Temming, A., 2011a. Growth in the brown shrimp Crangon crangon. I. Effects of food, temperature, size, gender, moulting, and cohort. Mar. Ecol. Prog. Ser. 435, $141-154$.

Hufnagl, M., Temming, A., 2011b. Growth in the brown shrimp Crangon crangon. II. Metaanalysis and modelling. Mar. Ecol. Prog. Ser. 435, 155-172.

Hughes, J.T., Matthiessen, G.C., 1962. Observations on the biology of the American lobster, Homarus americanus. Limnol. Oceanogr. 7, 414-421.

ICES, 2015. Report of the Working Group on Crangon Fisheries and Life History (WGCRAN), 18-20 May 2015, Ijmuiden, the Netherlands. ICES CM 2015/SSGEPD:07 (58 pp).

IPCC, 2013. In: Stocker, T.F., Qin, D., Plattner, G.K., Tignor, M., Allen, S.K., Boschung, J., Nauels, A., Xia, Y., Bex, V., Midgley, P.M. (Eds.), Climate Change 2013: The Physical Science Basis. Contribution of Working Group I to the Fifth Assessment Report of the Intergovernmental Panel on Climate Change. Cambridge University Press, 
Cambridge, United Kingdom and New York, NY, USA. http://dx.doi.org/10.1017/ CBO9781107415324. (1535 pp).

Kaplan, E.L., Meier, P., 1958. Nonparametric estimation from incomplete observations. J. Am. Stat. Assoc. 53, 457-481.

Knust, R., 1990. The black spot disease in Crangon crangon (L.) of the German Bight. In: ICES C.M. E: 32 Ref. K. Mar. Env. Quality Comm. (11 pp).

Laufer, H., Demir, N., Biggers, W.J., 2005. Response of the American lobster to the stress of shell disease. J. Shellfish Res. 24, 757-760.

Lloyd, A., Yonge, C., 1947. The biology of Crangon vulgaris L. in the Bristol Channel and Severn Estuary. J. Mar. Biol. Assoc. UK 26, 626-661.

Malloy, S.C., 1978. Bacteria induced shell disease of lobsters (Homarus americanus). J. Wildl. Dis. 14, 2-10.

Mantel, N., 1966. Evaluation of survival data and two new rank order statistics arising in its consideration. Cancer Chemother. Rep. 50, 163-170.

Martin, G.G., Quintero, M., Quigley, M., Khosrovian, H., 2000. Elimination of sequestered material from the gills of decapod crustaceans. J. Crustac. Biol. 20, 209-217.

Meres, N.J., Ajuzie, C.C., Sikaroodi, M., Vemulapalli, M., Shields, J.D., Gillevet, P.M., 2012. Dysbiosis in epizootic shell disease of the American lobster (Homarus americanus). J. Shellfish Res. 31, 463-472.

Pinn, E.H., Ansell, A.D., 1993. The effect of particle size on the burying ability of the brown shrimp Crangon crangon. J. Mar. Biol. Assoc. UK 73, 365-377.

Reiser, S., Herrmann, J.P., Temming, A., 2014. Thermal preference of the common brown shrimp (Crangon crangon, L.) determined by the acute and gravitational method. J. Exp. Mar. Biol. Ecol. 461, 250-256.

Revill, A.S., Holst, R., 2004. Reducing discards of North Sea brown shrimp (C. crangon) by trawl modification. Fish. Res. 68, 113-122.

Rosen, B., 1967. Shell disease of the blue crab, Callinectes sapidus. J. Invertebr. Pathol. 9, 348-353.

Schlotfeldt, H., 1972. Jahreszeitliche Abhängigkeit der 'Schwarzfleckenkrankheit' bei der Garnele, Crangon crangon (L). Ber. Wissen. Komm. Meeresfors. 22, 397-399.

Scholnick, D.A., Burnett, K.G., Burnett, L.E., 2006. Impact of exposure to bacteria on metabolism in the penaeid shrimp Litopenaeus vannamei. Biol. Bull. 211, 44-49.

Shields, J.D., 2013. Complex etiologies of emerging diseases in lobsters (Homarus americanus) from Long Island Sound. Can. J. Fish. Aquat. Sci. 70, 1576-1587.

Siegel, V., Damm, U., Neudecker, T., 2008. Sex-ratio, seasonality and long-term variation in maturation and spawning of the brown shrimp Crangon crangon (L.) in the German Bight (North Sea). Helgol. Mar. Res. 62, 339-349.

Sindermann, C.J., 1979. Pollution-associated diseases and abnormalities of fish and shellfish: a review. Fish. Bull. 76, 717-749.
Smith, V.J., Ratcliffe, N., 1980. Cellular defense reactions of the shore crab, Carcinus maenas: in vivo hemocytic and histopathological responses to injected bacteria. J. Invertebr. Pathol. 35, 65-74.

Smolowitz, R.M., Bullis, R.A., Abt, D.A., 1992. Pathologic cuticular changes of winter impoundment shell disease preceding and during intermolt in the American lobster, Homarus americanus. Biol. Bull. 183, 99-112.

Smolowitz, R.M., Chistoserdov, A., Hsu, A., 2005. A pathological description of epizootic shell disease in the American lobster Homarus americanus. J. Shellfish Res. 24, 749-756.

Tarrant, A.M., Franks, D.G., Verslycke, T., 2012. Gene expression in American lobster (Homarus americanus) with epizootic shell disease. J. Shellfish Res. 31, 505-514.

Teschke, M., Wendt, S., Kawaguchi, S., Kramer, A., Meyer, B., 2011. A circadian clock in antarctic krill: an endogenous timing system governs metabolic output rhythms in the euphausid species Euphausia superba. PLoS One 6, e26090.

Thibodeaux, L.K., Burnett, K.G., Burnett, L.E., 2009. Energy metabolism and metabolic depression during exercise in Callinectes sapidus, the Atlantic blue crab: effects of the bacterial pathogen Vibrio campbellii. J. Exp. Biol. 212, 3428-3439.

Tiews, K., 1954. Die biologischen Grundlagen der Büsumer Garnelenfischerei. Ber. Deut. Wiss. Komm. 3, 235-269.

Tiews, K., 1970. Synopsis of biological data on the common shrimp Crangon crangon (Linnaeus, 1758). FAO Fish. 57, 1167-1224.

Tlusty, M.F., Metzler, A., 2012. Relationship between temperature and shell disease in laboratory populations of juvenile American lobsters (Homarus americanus). J. Shellfish Res. 31, 533-541.

Tlusty, M.F., Smolowitz, R.M., Halvorson, H.O., DeVito, S.E., 2007. Host susceptibility hypothesis for shell disease in American lobsters. J. Aquat. Anim. Health 19, 215-225.

Van Donk, E., De Wilde, P.A.W.J., 1981. Oxygen consumption and motile activity of the brown shrimp Crangon crangon related to temperature and body size. Neth. J. Sea Res. 15, 54-64.

Vogan, C.L., Costa-Ramos, C., Rowley, A.F., 2001. A histological study of shell disease syndrome in the edible crab Cancer pagurus. Dis. Aquat. Org. 47, 209-217.

Vogan, C.L., Costa-Ramos, C., Rowley, A.F., 2002. Shell disease syndrome in the edible crab, Cancer pagurus -isolation, characterization and pathogenicity of chitinolytic bacteria. Microbiol. 148, 743-754.

White, K., Ratcliffe, N., 1982. The segregation and elimination of radio and fluorescent belled marine bacteria from the haemolymph of the shore crab, Carcinus maenas. J. Mar. Biol. Assoc. UK 62, 819-833. 